\title{
Unintended Consequences of National Climate Policy on International Electricity Markets-Case Finland's Ban on Coal-Fired Generation
}

\author{
Anahita Farsaei *, Sanna Syri ${ }^{\mathbb{D}}$, Ville Olkkonen and Ali Khosravi \\ Department of Mechanical Engineering, School of Engineering, Aalto University, Otakaari 4, \\ 02150 Espoo, Finland; sanna.syri@aalto.fi (S.S.); ville.olkkonen@aalto.fi (V.O.); ali.khosravi@aalto.fi (A.K.) \\ * Correspondence: anahita.farsaei@aalto.fi
}

Received: 16 March 2020; Accepted: 10 April 2020; Published: 14 April 2020

check for updates

\begin{abstract}
Finland has adopted a high profile in climate change mitigation. A national target of achieving carbon neutrality by 2035 has been declared. As a part of this, the use of coal for energy purposes has been banned from May 2029 onwards. The Nordic electricity market was a world fore-runner in creating a liberalized, multi-national electricity market in the 1990s. At present, the electricity systems of Finland, Sweden, and Norway are already very low-carbon. The Baltic countries Estonia, Latvia, and Lithuania joined the Nordic market about a decade ago. Estonian electricity production is the most carbon-intensive of all the EU countries due to the extensive use of domestic oil shale. Especially Lithuania still suffers from capacity deficit created by the closure of the Soviet time nuclear reactor Ignalina in Lithuania. This paper presents the ambitions of the EU and national level energy and climate policies and models the multi-national impacts of Finland's forthcoming closure of coal-fired generation. We also take into account Sweden's planned decrease in nuclear generation. We find that these national-level policies have an impact on the Baltic countries as reduced import possibilities and increasing electricity prices, and the expected rise of the $\mathrm{EU} \mathrm{CO}_{2}$ allowance prices amplifies these. We further find that the abandonment of coal and nuclear power plants increases the net import and increases $\mathrm{CO}_{2}$ emissions in neighboring regions.
\end{abstract}

Keywords: decarbonization; electricity import; $\mathrm{CO}_{2}$ emission

\section{Introduction}

The UNFCCC Paris agreement put a target to limit future temperature increases to "well below $2{ }^{\circ} \mathrm{C}^{\prime \prime}$ above pre-industrial levels by governments [1]. The EU has set different targets for 2020, 2030, and 2050 in order to tackle climate change. The EU aims at rising shares of renewables in total energy consumption by $20 \%$ and $32 \%$ in 2020 and 2030, respectively. It also set a target to cut the greenhouse gas emission by $20 \%$ and at least $40 \%$ and $80 \%$ by 2020,2030 , and 2050 , respectively [2]. As decarbonizing especially the transport sector is difficult, decarbonization in electricity is crucial.

Following the global trend, all Nordic countries aim to implement targets in order to reach carbon neutrality. With this regard, Finland has set different targets in order to pave the way for carbon neutrality. The government of Prime Minister Sipilä in May 2015 set targets to increase the use of renewables in transportation to $40 \%$ by 2030 . Additionally, the use of imported oil should be halved from current levels and the use of domestic energy sources increased up to 55\% [3]. Recently, a new regulation has been implemented to ban the use of coal in energy production by 2029 [4]. This will be challenging for several cities in Finland, especially for Helsinki, as one-third of its energy needs are provided by coal [3].

Coal has been used in Finland both in condensing power plants ("electricity-only") and in combined heat and power (CHP) plants. CHP plants in city-level district heat (DH) networks are 
a vital backbone for the heating system in Finland, similarly to, e.g., Denmark, the Baltic countries, and most East European countries. The main fuels are coal and natural gas. CHP plants are used in these countries so that maximal total efficiency is reached: for coal-fired plants the electrical efficiency is in the order of $30 \%$ and heat efficiency in the order of $60 \%$. For natural gas combined cycle gas turbine (CCGT ), the electricity and heat efficiencies are at best about $45 \%$ or more, and about $45 \%$, respectively [5].

Coal-fired condensing power has been used on the Finnish electricity market, but in recent years the existing plants have been either dismantled or withdrawn from the normal electricity market. The reason for this has been low profitability due to low electricity market prices. For instance, Inkoo plants built in 1974-1978 of four 250 MW will be completely dismantled by spring 2020 [6]. Concerning the last coal-fired condensing plant, Meri-Pori of $565 \mathrm{MW}$, built in 1994, currently has more than 50\% power share (308 MW) is selected for a peak-load capacity reserves contract organized by the Energy Authority [7]. Thus, the ban on coal use for energy purposes is practically an issue for DH systems, where coal is used both in CHP plants and in older heat-only boilers (HOB).

District heat systems in Finland are very energy-efficient, but they are also a challenge in the efforts for carbon neutrality. Currently, 51\% of fuels used in DH in Finland are fossil fuels or peat, which is a high-emission domestic fuel in Finland [8]. The high heat demand density in cities in Finland excludes many alternative solutions. For instance, total replacement by either small scale biomass boilers or by large-scale biomass-fueled power plants is not viable due to issues of logistics, local air pollution or the increase in total biomass demand, which challenges sustainability and cost competitiveness. Similarly, there is only a limited amount of heat sources available for heat pump technologies and limited space available for large-scale ground source heat pumps.

At present, the electricity systems of Finland, Sweden, and Norway are already very low-carbon and this region is a world fore-runner towards $\mathrm{CO}_{2}$ emission-free energy systems. The main $\mathrm{CO}_{2}$ challenges are heating and transport sectors and industrial process emissions.

The Baltic countries Estonia, Latvia, and Lithuania joined the Nordic market about a decade ago. Estonian electricity production is the most carbon-intensive of all the EU countries due to the extensive use of domestic oil shale [9]. Especially Lithuania still suffers from capacity deficit created by the closure of the Soviet time nuclear reactor Ingalina in Lithuania [10].

National policies can have important multi-national impacts, and these are usually not considered when designing national-level policies. This paper studies the impacts of the Finnish ban on coal use on electricity prices, on $\mathrm{CO}_{2}$ emissions, and on the import-export balances of the Nordic-Baltic electricity market. Additionally, we assume that Finland would also reduce and gradually give up the use of domestic high-emission fuel peat. We also take into account the existing policies and decisions in Sweden to reduce the amount of nuclear power. This paper presents the significant multi-national impacts of these national-level decisions, using the electricity market model Enerallt developed at Aalto University [11,12].

\section{Literature Review}

Several studies have assessed the probable effects of the EU countries' targets along with ambitious $\mathrm{CO}_{2}$ reduction goals. Newcomer and Apt [13] examined the effect of banning the construction of new coal-fired power plants on dispatch order, $\mathrm{CO}_{2}$ emissions, and fuel which is used under different scenarios until 2030 in the US. It is shown that this will lead to a dramatic increase in natural gas use and price. However, it is discussed that it would be better to reduce $\mathrm{CO}_{2}$ by applying $\mathrm{CO}_{2}$ emission price which could be economically more efficient. Lund and Mathiesen [14] have modeled the future energy system of Denmark. Target years selected to investigate the possibility of switching to $50 \%$ and $100 \%$ renewable energy systems are 2030 and 2050, respectively. Venkatesh et al. [15] studied the coal electricity generators phase-out implications on $\mathrm{SO}_{2}, \mathrm{NO}_{x}$, and life cycle greenhouse gases (GHG) emissions in the US in the short-term. They have discussed five scenarios regarding emissions of the plants which were retired. Results indicate that the life cycle GHG emissions were reduced by less 
than $4 \%$ in almost all scenarios. The decrease in $\mathrm{SO}_{2}$ and $\mathrm{NO}_{\mathrm{x}}$ would be higher. It is suggested to consider the regional impact of the emissions as well as the amount of emissions which are reduced. Elliston, MacGill, and Diesendorf [16] have compared scenarios based on medium and low carbon fossil fuel with a previously published scenario of $100 \%$ renewable electricity in 2030 for Australia. In the first scenario, they utilized gas-fired combined cycle gas turbines and open cycle gas turbines. In the second scenario, they consider coal with carbon capture and storage plus peak load open cycle gas turbines. Then a model of gas-fired combined cycle gas turbines with carbon capture and storage plus peak load open cycle gas turbines is proposed. Results indicate that most cases can not economically compete with a $100 \%$ renewable scenario. This is due to the carbon price of $56 \$ / \mathrm{tCO}_{2}$ and gas price of $11 \$ / G J$. Only in limited cases when they decrease these prices, the fossil scenarios could bring a lower cost than the $100 \%$ renewable electricity scenario. Heinrichs and Markewitz [17] have analyzed the long-term impacts of phasing out coal in Germany by 2050. For this purpose, they have presented three scenarios, one of which considers phasing out coal. Besides, they discussed two other scenarios with the usual lifetime of power plants and obtaining $\mathrm{CO}_{2}$ targets with a more cost-efficient allocation of power plants which does not ban the use of coal. Results show that this ban could not be successful in terms of making a dramatic reduction in $\mathrm{CO}_{2}$. Pilpola and Lund [18] have investigated possible risks and alternative energy systems in order to achieve Finland's energy targets to ban the use of coal. This analysis is done by applying the national energy system model with a 1-h resolution through four scenarios for the Finnish energy system in 2030 and 2050. By considering future demand uncertainties, scenarios provide solutions for the risks with nuclear power and biomass sustainability. In this model, Finland is considered as a single node, without power and heat flow limitations. The power system is assumed to be connected to the Nordpool as one price area with a single transmission line and exchange would be for balancing supply and demand. Results show that even in an extreme case, a feasible energy system solution can be achieved. Hong, Qvist, and Brook [19] analyzed replacing nuclear with solar and wind in Sweden. The current situation was compared with scenarios of replacing nuclear with solar and wind power. It is shown that this replacement can not be economically nor environmentally friendly. In fact, this replacement needs $154 \mathrm{GW}$ of wind power that increases the electricity cost. Expanding transmission lines with other countries and production from CHP plants can half the needed wind and photovoltaic capacity. However, it will double the greenhouse gas emissions. Hansen, Mathiesen, and Skov [20] have used EnergyPLAN as a tool to survey scenarios for Germany to achieve $100 \%$ renewable energy by 2050. Based on this study, this goal could be achievable. However, there are challenges, most importantly, the resource potentials, especially the constrained amount of biomass.

Together these studies provide insights into GHG emissions and surveyed long-term scenarios to replace their energy systems with renewables. However, these studies only focus on one country and the effect of changes on neighbors has been neglected. This paper discusses the implications of phasing out coal and peat in Finland on the Nordic and Baltic countries and the strongly interconnected Nordic and Baltic electricity market. Figure 1 shows the region with day-ahead prices. There exist strong interconnections between the Nordic countries. The Baltic countries are currently still a different synchronous area but are connected to the Nordic area with HVDC links between Finland and Estonia and between Lithuania and Sweden. The reader should note that prices in Figure 1 are lower than normal due to the exceptionally mild winter.

Moreover, this paper attempts to show the impacts of Sweden's nuclear generation on these countries' electricity markets. Therefore, this study makes a major contribution to research on the Nordic electricity market by demonstrating the effects of Finland's major target and the possible implications of Sweden's debate on nuclear production. Compared to previous studies, the impacts on neighboring countries are explored. 


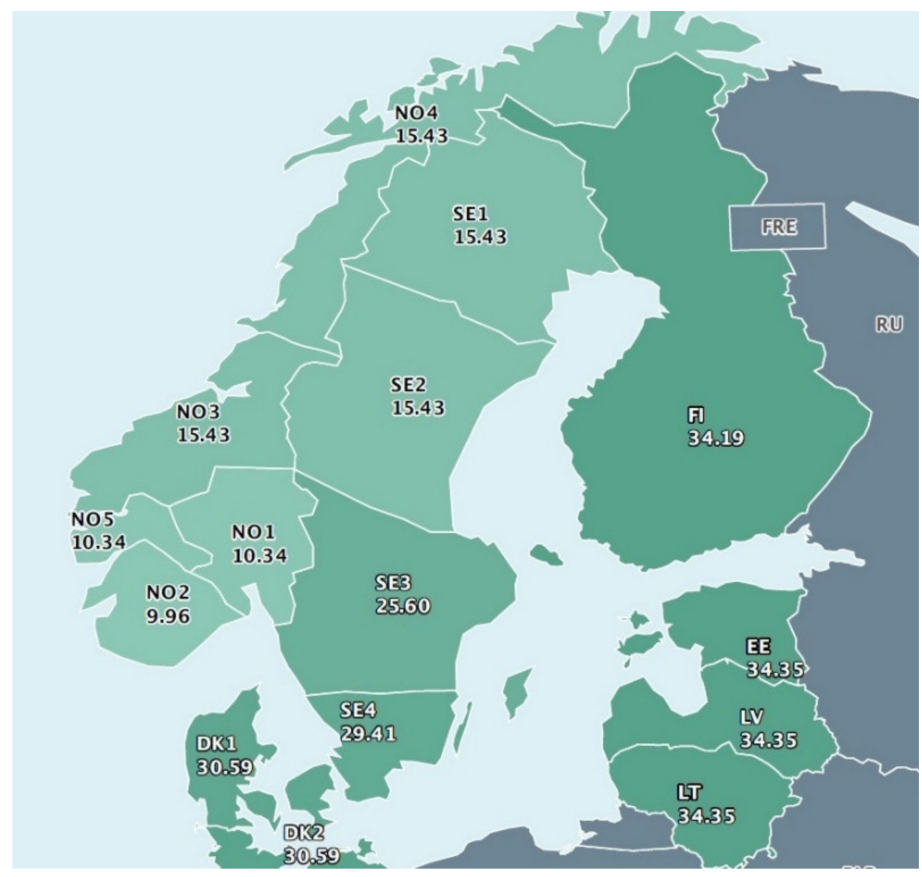

Figure 1. Nordic-Baltic day-ahead electricity market overview on 2/3/2020 [21]. For country abbreviations, see Table 1.

\section{European and National Energy and Climate Policies in the Region}

The EU energy policy is set to provide consumers with sustainable, affordable and secure energy supplies [22]. The Energy Trilemma Index which is published by the World Energy Council determines all these three criteria for a total of 128 countries all over the world. The Nordic and the Baltic countrie's most recent ranking can be found in Table 1 . Estonia has the worst raking among others in sustainability. This is owing to the environmental effects of oil shale. All Baltic countries have an issue regarding the affordability of energy.

Table 1. Energy Trilemma Index for target countries in 2019 [23].

\begin{tabular}{ccccc}
\hline Country & Index Rank & Energy Security Rank & Energy Equity Rank & Environmental Sustainability Rank \\
\hline Sweden (SE) & 2 & 1 & 40 & 3 \\
Denmark (DK) & 3 & 2 & 28 & 2 \\
Finland (FI) & 5 & 3 & 33 & 28 \\
Norway (NO) & 11 & 73 & 20 & 5 \\
Latvia (LV) & 22 & 4 & 60 & 25 \\
Estonia (EE) & 30 & 31 & 38 & 63 \\
Lithuania (LT) & 36 & 74 & 51 & 21 \\
\hline
\end{tabular}

A milestone in the EU Commission ambitious energy and climate policy was legislated in 2009, publishing the so-called 20-20-20 targets, i.e., the reduction of greenhouse gases (GHG) by 20\%, the share of renewable energy in the final consumption of $20 \%$ and an indicative target of $20 \%$ improvement in energy efficiency by the year 2020 compared to 2005 [24]. Renewable energy target was divided amongst countries as binding requirements on the share of renewable energy. The national targets ranged from $49 \%$ for Sweden to $11 \%$ for Luxembourg, as the effort sharing took into account the present level and the potential for an increase in each country [25]. The Commission published further targets for the year 2030 in 2014. Renewables and energy efficiency targets were revised in 2018 [26]. The renewables policies aim at rising shares of renewables in total final energy consumption by $20 \%$ and $32 \%$ in 2020 and 2030, respectively. The targets to cut the GHG emissions are $20 \%$ and at least $40 \%$ and $80 \%$ by 2020,2030 , and 2050 , respectively [2]. 
The EU 2020 policies made most EU countries design substantial support mechanisms and policies for renewable energy. Substantial efforts have been made in most EU countries to increase especially renewable energy sources (RES) electricity. However, switching to renewable sources could dramatically affect the electricity market. Over the past decade, increasing renewables in power generation have led to a fall in wholesale electricity prices. Low or zero marginal costs of renewables could bring about negative electricity prices during some hours. While this phenomenon was common in countries like Germany and Denmark, Finland experienced its first negative electricity prices for four hours on 10 February. A boost in wind energy due to a storm and a workers' strike in the paper industry decreased prices in the early morning. These impacts on prices would be barriers for investors to expand the market. In the long-run, this shortage of investment could cause severe effects in market competition and security of supply.

As part of the EU's long-term energy and climate policy, an emissions trading system (ETS) for $\mathrm{CO}_{2}$ emissions from large-scale sources was started at the beginning of 2005 [27]. The EU's ETS thus forms a market-based price for $\mathrm{CO}_{2}$ emissions, with a daily market-based formation of the allowance price. The price has varied significantly since the beginning, with the highest values around $30 € /$ tonCO and the lowest at a few cents in 2007 at the end of the first trading period. Since the global economic crisis, the price collapsed and stayed between 5-10€/tonCO $\mathrm{C}_{2}$ until the year 2018. Recently, the price has increased to about $20 € /$ tonCO $\mathrm{CO}_{2}$, and the general expectation is that with more and more stringent climate policy, the prices will continue to increase in the future as well.

Table 2 presents carbon intensities for the Nordic and Baltic countries. Estonia has the highest amount as its emission is significantly higher due to its considerable production by oil shale, while Norway has the least amount. Norway's electricity production is $95 \%$ hydropower, and Norway is typically a net exporter, for instance helping to balance the highly variable production of Denmark, where currently $46 \%$ of all generation is wind power. Norway is also a net exporter to Sweden and further to Finland [28].

Table 2. Carbon intensities of electricity for the Nordic-Baltic countries in 2013 [9,29].

\begin{tabular}{cc}
\hline Country & $\begin{array}{c}\text { Carbon Intensities of Gross Electricity Production } \\
\text { (Combustion Only) (g/KWh) }\end{array}$ \\
\hline Finland (FI) & 171 \\
Sweden (SE) & 16 \\
Estonia (EE) & 1020 \\
Latvia (LV) & 134 \\
Lithuania (LT) & 204 \\
Norway (NO) & 8 \\
Denmark (DK) & 316 \\
Poland (PL) & 770 \\
\hline
\end{tabular}

\subsection{Finland}

Finland's national RES target of 38\% of renewable energy in final consumption specified by the EU was among the most ambitious in the EU, third only by Sweden and Latvia with $46 \%$ and $40 \%$, respectively. The share was 37\% in 2018, and it seems that Finland will meet the target [30]. jThe feed-in tariff for wind power made the amount of wind capacity increase from $197 \mathrm{MW}$ in 2010 to 2041 MW in 2018 [4]. The target was to have about 2000 MW or 6 TWh in 2020. Finland has set various objectives that are in line with the EU targets for 2030. The long-term aim is to become a carbon-neutral society. Reducing greenhouse gas emissions from other sectors than those included in the $\mathrm{EU} \mathrm{CO}_{2}$ emissions trading system by $39 \%$ by 2030 , increasing share of renewables in energy consumption, raising renewable energy use in transport, which could have a vital effect on carbon emission reduction, and halving the use of imported oil are part of these objectives [31].

One of the major targets is phasing out coal in energy production. Fuel's share in electricity and heat production in 2016 is shown in Figure 2. As it is seen, coal-fired CHP plays a vital role in 
electricity and heat production in Finland. Thus, removing this fuel from the energy sector could affect these markets.

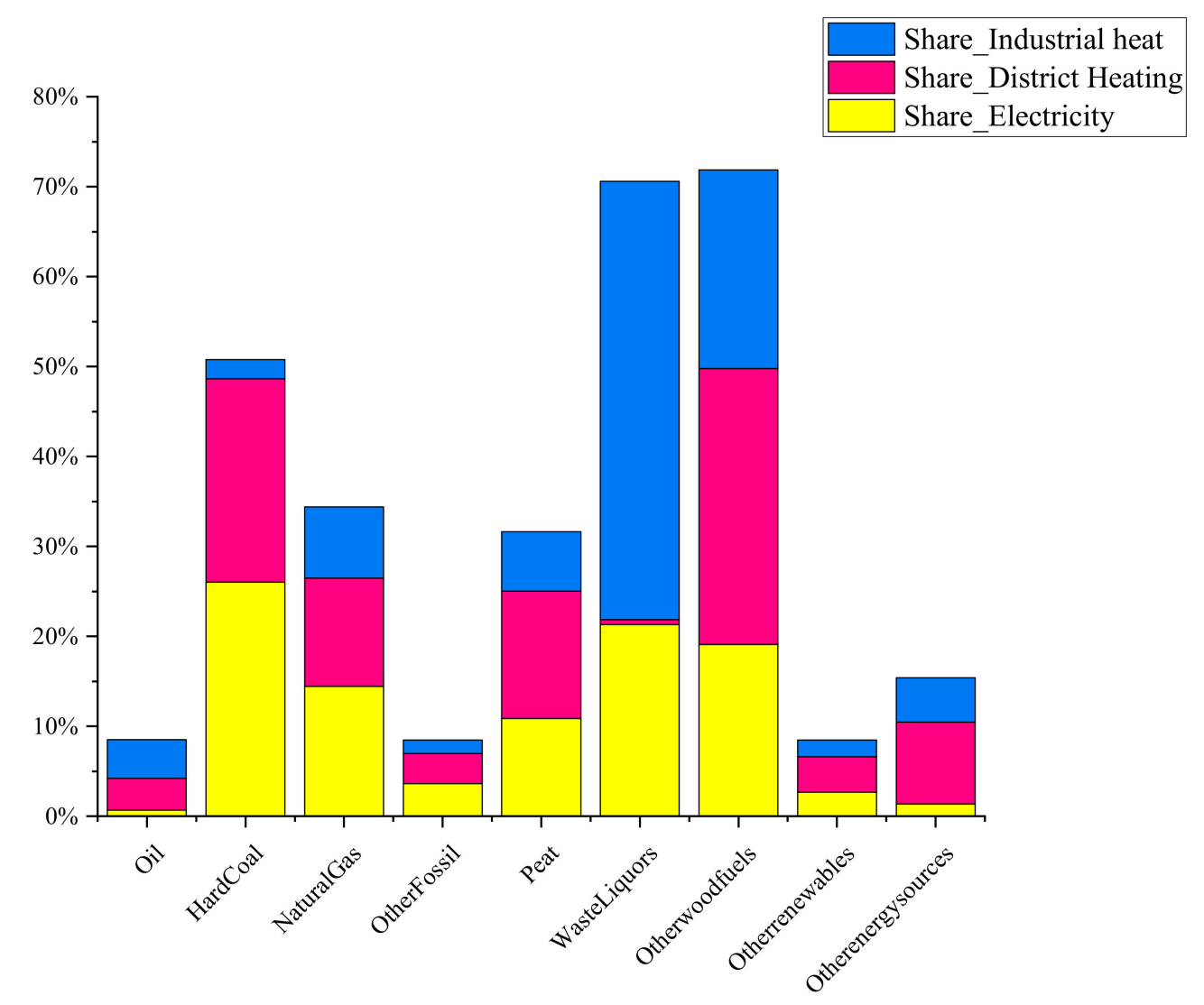

Figure 2. The sectoral uses of combustible fuels in electricity and heat production in Finland, 2016, indicating the most important uses of combustible fuels [32].

Carbon-neutrality means that $\mathrm{CO}_{2}$ emissions would not exceed the natural sinks. Especially forests are a very large natural carbon sink (27 Mtonnes $\mathrm{CO}_{2 \mathrm{eq}}$ in 2017), and the current trend of increasing wood use in the forest industry and for energy purposes threatens these sinks, also posing a significant additional challenge in reaching carbon neutrality.

\subsection{Sweden}

Sweden is the largest country of the Nordic-Baltic electricity market, with around 10 million people population and a GDP of 471.21 billion Euros in 2018 [33,34]. The total electricity production is expected to be 174 TWh by 2030 .

Key climate and energy targets for Sweden for 2030 can be expressed as follows:

- $\quad$ Energy use would be 50\% more efficient than in 2005

- Emission from non-ETS activities would be decreased by $63 \%$ compared to 1990.

- Transport's emission would fall by $70 \%$ compared to 2010

Sweden has no precise target for its renewable energy by 2030. However, the Swedish Energy Agency has announced the 2016 reference scenario, which mentioned that $65 \%$ of gross final consumption of energy would be from renewable sources by 2030 [35].

\subsection{Estonia}

Estonia is a country with around 1 million people population and a GDP of 26.04 billion Euros in 2018 [33,34]. Its total electricity production is expected to be 9 TWh by 2030. 
In line with the EU energy and climate policies, Estonia has put targets to develop its status in the energy sector. For 2030, their main objectives can be expressed as follows [36]:

- $\quad$ Electricity system is synchronized with the EU

- $80 \%$ of generated heat is renewable-based

- $50 \%$ of domestic final electricity consumption is renewable-based

- Unsubsidized and open fuel and electricity market would operate

- Market concentration in the gas market would dramatically fall

- Gas market supplier's share would be less than $70 \%$

- Gas market seller's share would be less than $32 \%$

\subsection{Latvia}

Latvia is a country with around 2 million people population and a GDP of 29.15 million Euros in 2018 [33,34]. Its expected that total electricity production is estimated to grow to 7 TWh by 2030. It is connected with Lithuania and Estonia through electricity transmission lines. This country's objectives for 2030 have been summarized in Table 3.

Table 3. EU and Latvia objectives for 2030 [37].

\begin{tabular}{ccc}
\hline Policy Outcome & EU & Latvia \\
\hline GHG emission reduction target (\% compared to 1990) & -40 & -55 \\
Non-ETS activities (\% compared to 2005) & -30 & -6 \\
ETS activities (\% compared to 2005) & -43 & - \\
Share of energy produced from RES in gross final energy consumption (\%) & 32 & 45 \\
Share of energy produced from RES in gross final energy consumption in transport (\%) & 14 & 14 \\
Share of advanced biofuels in gross final energy consumption in transport & 3.5 & 3.5 \\
Increase in energy efficiency (\%) & 32.5 & - \\
\hline
\end{tabular}

\subsection{Lithuania}

Lithuania is a country with around 2 million people population and a GDP of 45.26 in 2018 [33,34]. Its total electricity production would grow to 14 TWh by 2030 according to national estimates.

Lithuania's major climate and energy policy targets in 2030 are overviewed in Table 4.

GHG targets and shares of renewables in final energy consumption for selected countries are summarized in Table 5. Share of energy from renewable sources is also presented in Figure 3.

Table 4. Lithuania's key climate and energy policy objectives [38].

\begin{tabular}{ccc}
\hline Target & EU & Lithuania \\
\hline $\begin{array}{c}\text { GHG reduction targets according to } \\
\text { KP Doha amendment and Paris }\end{array}$ & At least $-40 \%$ & EU level target \\
agreement compared to 1990 level & & EU level target \\
GHG reduction targets in ETS sectors & $-43 \%$ & $-9 \%$ \\
$\quad$ compared to the 2005 level & & $-30 \%$ \\
GHG reduction targets in non-ETS & $27 \%$ & $45 \%$ \\
sectors compared to 2005 level & $14 \%$ & $15 \%$ \\
RES utilization target in final energy & $15 \%$ & EU level target \\
RES utilization target in transport & $27.3 \%$ & Energy intensity 1.5 times lower \\
Interconnectivity level & & than in 2017 \\
Energy Efficiency targets & &
\end{tabular}


Table 5. Selected countries targets by 2030 [32,34-37].

\begin{tabular}{ccccccc}
\hline Target & EU & FI & SE & EE & LV & LT \\
\hline Population (million) & 512 & 5.5 & 10 & 1 & 2 & 2 \\
GDP (million Euro) & $15,890,000$ & 234.37 & 471.21 & 26.04 & 29.15 & 45.26 \\
GHG targets in non-ETS sectors & $-30 \%$ & $-39 \%$ & $-50 \%--59 \%$ & $-13 \%$ & $-6 \%$ & $-9 \%$ \\
compared to 2005 level & $27 \%$ & $>50 \%$ & $65 \%$ & $42 \%$ & $45 \%$ & $45 \%$ \\
RES utilization target in final energy & $27 \%$ &
\end{tabular}

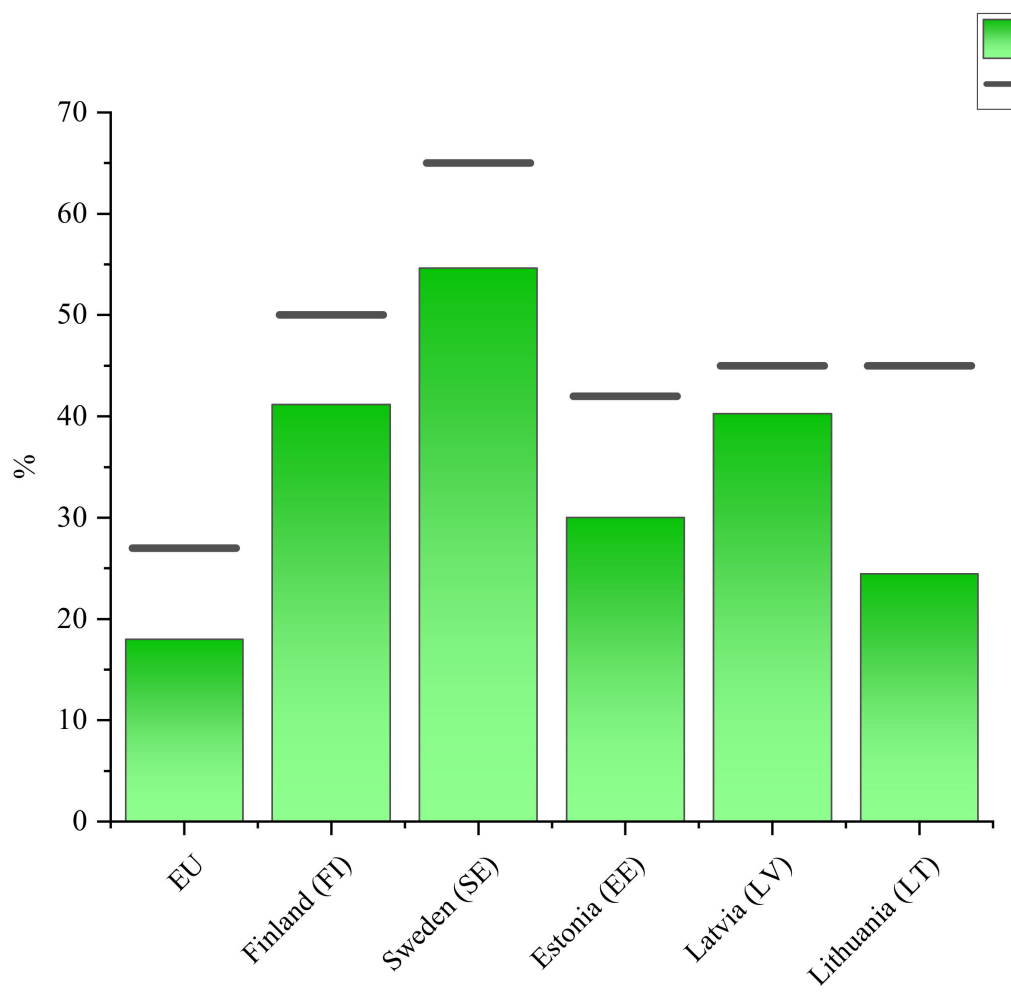

Figure 3. Share of energy from renewable sources in selected countries [35,37-40].

\section{Data and Methods}

This paper discusses the implications of phasing out coal and peat in Finland on Nordic and Baltic countries on the strongly interconnected Nordic and Baltic electricity market. Moreover, it attempts to show the impacts of Sweden's nuclear generation on these countries' electricity market. In order to understand how these changes in the national energy systems affect other countries, different energy system scenarios have been employed, which are described in Section 4.2. Furthermore, input data describing the national energy systems and data sources are presented in Section 4.3. The energy system analysis is conducted with a linear programming based model that is implemented in MATLAB. A detailed description of the energy system model is presented in Section 4.1.

\subsection{Modeling of the Energy System}

In the energy system analysis, both power and district heating sectors are included and the energy system operation is modeled in $24-\mathrm{h}$ intervals with hourly resolution. This represents the Nordic day-ahead power market. The description of the energy system model is presented below.

\subsubsection{Hydropower Simulation}

The short-term hydropower production planning in each bidding area $j$ is determined using a rolling interval method for the next $168 \mathrm{~h}$. Thus, the annual hydropower production planning problem 
is split into partially overlapping intervals $T$ and the usable reservoir content $V_{a_{j}, T}$ is determined for each planning interval, as presented in (1).

$$
V_{a_{j}, T}=\sum_{t}^{T} V_{j, t}-V_{j, T}+\sum_{t}^{T} Q_{i n_{j}, t} \forall j, t \in T
$$

In (1), $V_{j, T}$ presents the target reservoir level at the end of each planning interval, $V_{j, t}$ is the reservoir level in the hour $t$ and $Q_{i n_{j}, t}$ is the reservoir inflow in the hour $t$. The initial reservoir level at the beginning of the year $t_{0}$, the reservoir inflow in the hour $t$, and the reservoir level target at the end of the production planning interval $T$ are given as inputs to the model.

Moreover, in the planning interval, the usable reservoir content is then allocated to each hour in an iterative procedure based on three conditions, as presented in (2).

$$
\begin{gathered}
Q_{d_{j}, t}=Q_{d 1_{j}, t}+Q_{d 2_{j}, t}+Q_{d 3_{j}, t} \\
Q_{d 1_{j}, t}=Q_{m i n, t} \\
Q_{d 2_{j}, t}=d_{j, t}-\left(\sum_{i} p_{i j, t}+N T C_{j k}\right) i f d_{j, t}>\sum_{i} p_{i j, t}+N T C_{j k} \\
Q_{d 3_{j}, t}=\left(V_{a_{j}, T}-\left(\sum_{t} Q_{d 1_{j, t}}+Q_{d 2_{j}, t}\right)\right) \cdot \sum_{i} c_{i, t} p_{i, t} / \sum_{i} \sum_{t}^{T} c_{i, t} p_{i, t}
\end{gathered}
$$

Firstly, the outflow through the hydropower plant has to satisfy the minimum environmental flow requirement $Q_{\min , t}$, which is set to be $5 \%$ of the mean inflow during the planning interval [41]. Secondly, the remaining usable water in the reservoir is first allocated to the hours where electricity supply-demand balance in the bidding area $j$ is not achieved by other electricity production sources $p_{i j, t}$ (and/or importing transfer capacities $N T C_{j k}$ from the bidding area $k$ ). Finally, the remaining usable water in the reservoir is allocated based on the price dependent power supply curves taking into account the electricity demand in the bidding area $j$. The usable water discharge $Q_{d_{j, t}}$ is further constrained by the physical constraints of the hydropower unit that are represented by the maximum power output of the hydropower turbine $P$ and the turbine efficiency $e$, as presented in (3).

$$
Q_{d_{j}, t} \leq P / e
$$

The production planning interval $T$ is shifted by $24 \mathrm{~h}$ after each simulated day (i.e., after power and district heating sector optimization) and the initial conditions are updated to reflect the state reached by the plan up until the beginning of the new interval, as presented in (4).

$$
V_{j, t}=V_{j, t-1}+Q_{i n_{j, t}}-Q_{d_{j}, t-1}-W_{j, t}
$$

Moreover, as presented in (5), the regulated reservoirs have upper and lower limits that are given as inputs to the model. Consequently, the spilling in the hour $t$ is determined based on the upper limit and the current reservoir level $V_{j, t}$, as presented in (6).

$$
\begin{gathered}
V_{l_{j}} \leq V_{j, t} \leq V_{u_{j}} \\
W_{j, t}=\left\{\begin{array}{c}
0, \text { if } V_{j, t} \leq V_{u_{j}} \\
V_{j, t}-V_{u_{j}}, \text { if } V_{j, t}>V_{u_{j}}
\end{array}\right.
\end{gathered}
$$

\subsubsection{Power and District Heating Sector Optimization}

The power and district heating sector modeling presented in this paper is informed by the previous research of Nord Pool power market modeling presented in [11]. The objective function (7) is to 
minimize the short-term cost of electricity and district heating production in a production planning interval of $24 \mathrm{~h}$ and it is subject to constraints presented in (8)-(11).

$$
\begin{gathered}
\min _{p_{i j, t}, p_{i j k, t}, h_{i j k, t}}\left(\sum_{i} \sum_{j} \sum_{t} c_{i j, t} p_{i j, t}+\sum_{i} \sum_{j} \sum_{k \neq j} \sum_{t} c_{i j, t} p_{i j k, t}+\sum_{i} \sum_{j} \sum_{n} \sum_{t} c_{i j, t} h_{i j n, t}\right) \\
\sum_{i} p_{i k, t}+\sum_{i} \sum_{j} p_{i j k, t}-\sum_{i} \sum_{n} h_{i k n, t}=d_{k, t}, \forall k \neq j, n, t \\
\sum_{i} \sum_{k \neq j} p_{i j k, t} \leq N T C_{j k, t}, \forall j, t \\
0 \leq \sum_{i} p_{i k, t}+\sum_{i} \sum_{j} p_{i j k, t} \leq P_{i j, t}, \forall i, j, t \\
p_{i j, t}-p_{i j, t-1} \leq r_{i j} P_{i j, t}
\end{gathered}
$$

In (7) $p_{i j, t}$ represents the power supply of technology $i$ in bidding area $j, p_{i j k, t}$ is the power supply of technology $i$ in the bidding area $j$ that is exported to the bidding area $k$ and $c_{i j, t}$ is the short-term marginal cost of production for technology $i$ in the bidding area $j$. Moreover, in (7), $h_{i j n, t}$ represents the heat supply of technology $i$ in bidding area $j$ in the DH network $n$ and $c_{i j, t}$, is the short-term marginal cost of heat conversion of technology $i$ in the bidding area $j$. Equation (8) represents the energy conservation law and $d_{k, t}$ in (8) is the electricity demand in the bidding area $k$. Moreover, in (8), $h_{i k n, t}$ is the electricity demand of heat conversion technology $i$ that is consumed in the heat conversion process (e.g., heat pump or electric heat-only boiler). Equation (9) represents the constraint for the electricity export between bidding areas and $N T C_{j k, t}$ is the net transmission capacity between bidding areas $j$ and $k$. Equation (10) represents the constraint for the power supply and $P_{i j, t}$ in (10) is the available electricity generation capacity for the technology $i$ in the bidding area $j$. Finally, Equation (11) represents the ramping constraint and $r_{i j}$ in (11) is the ramping factor. In (7)-(11), $t$ is the hour index.

The external market area that is interconnected through transmission lines to the bidding area $j$, is included in the power sector modeling as an artificial node with an exogenous electricity spot price. The available power supply in the external market area is set to be equal to the sum of export capacities and electricity demand in the hour $t$. The corresponding short-term marginal cost of production is set to be equal to the electricity spot price in the external market area.

The district heating (DH) sector within the bidding area $k$ is divided into DH nodes $n$ and it is subject to constraints presented in (12)-(14).

$$
\begin{gathered}
\sum_{i} h_{i k n, t}+\sum_{i} p_{i k, t} \theta_{i, t}+\sum_{i} \sum_{j} p_{i j k, t} \theta_{i, t}=q_{j k, t}, \forall j, k, t \\
\theta_{i, t}=\frac{H_{i j, t}}{P_{i j, t}} \\
0 \leq \sum_{i} h_{i j k, t} \leq H_{i j k, t}, \forall j, k, t \\
q_{i j, t}-q_{i j, t-1} \leq r_{i j} H_{i j, t}
\end{gathered}
$$

Equation (12) represents the conversion law and $q_{j k, t}$ is the heat demand in the DH network $n$ in bidding area $k$. In order to formulate the problem in linear form, in (12), the heat supply of CHP technology $i$ is coupled to the power supply of CHP technology $p_{i, t}$ by a heat-to-power ratio $\theta_{i, t}$. Equation (13) represents the constraints for the heat supply and $H_{i k n, t}$ is the available heat conversion capacity for the technology $i$ in bidding area $k$ in the DH network $n$. Finally, Equation (14) represents the ramping constraints. The power and district heating sector model is formulated as a linear 
programming problem, and the implementation is carried out using MATLAB. The optimization algorithm linprog (dual-simplex) is used.

\subsection{Scenarios}

In order to understand how banning the use of coal and peat in Finland affects other countries, different scenarios have been employed. Scenarios are summarized in Table 6. The design of the scenarios is based on the changes which could clarify results. Scenarios are applied both for the year 2016 (Scenario 1-5) and the year 2030 (Scenario 6-19) in order to compare the expected outcomes with the base scenario. The year 2016 is used as a reference year to ensure data availability with all different sources to relatively up to date input data.

Table 6. Scenarios summary.

\begin{tabular}{|c|c|c|c|}
\hline \multirow{2}{*}{ No. } & \multirow{2}{*}{ Year } & \multicolumn{2}{|c|}{ Scenario Description for Finland } \\
\hline & & Removed & Added \\
\hline 1 & & - & - \\
\hline 2 & & Coal & - \\
\hline 3 & 2016 & Coal & Biomass \\
\hline 4 & & Coal + peat & Biomass instead of Coal \\
\hline 5 & & Coal + peat & Biomass \\
\hline 6 & & - & - \\
\hline 7 & & Coal & - \\
\hline 8 & 2030-constant nuclear for SE & Coal & Biomass \\
\hline 9 & & Coal + peat & Biomass instead of Coal \\
\hline 10 & & Coal + peat & Biomass \\
\hline 11 & & - & - \\
\hline 12 & & Coal & - \\
\hline 13 & 2030-DECREASE Nuclear for SE & Coal & Biomass \\
\hline 14 & & Coal + peat & Biomass instead of Coal \\
\hline 15 & & Coal + peat & Biomass \\
\hline 16 & 2030-DECREASE Nuclear for SE, & Coal & - \\
\hline 17 & Connection with Norway excluded, & Coal & Biomass \\
\hline 18 & Norway's net import is considered & Coal + peat & Biomass instead of Coal \\
\hline 19 & constant at 2016 level & Coal + peat & Biomass \\
\hline
\end{tabular}

The year 2030 is studied under three assumptions. As nuclear production in Sweden is still a debate, to gain a detailed understanding of the results, this study is carried out by considering two cases for nuclear generators in Sweden. First, it is assumed that nuclear capacity in Sweden would be the same as its amount in 2016 (Scenario 6-10). Then it is reduced based on the EU's scenarios for 2030 (Scenario 11-15). Besides, to capture the relations between Finland, Sweden, and the Baltic countries, we made a sensitivity analysis where transmission connections from Norway are assumed constant at the 2016 level also in 2030 (Scenarios 16-19). Each case, except the last one, considers five scenarios. The base scenarios model is presented by the power generations in 2016 (Scenario 1) and expected capacities by 2030 (Scenarios 6,11). In the next step, coal-based generators have been omitted from Finland's capacity mix (Scenario 2,7,12,16). Then, the reduced capacity in the previous scenario is replaced by similar biomass capacity (Scenarios 3,8,13,17). Next, peat-based producers are out (Scenarios 4,9,14,18). Then, the decreased capacity is replaced by similar biomass CHP generation (Scenarios 5,10,15,19). Figure 4 shows the aforementioned scenarios. 


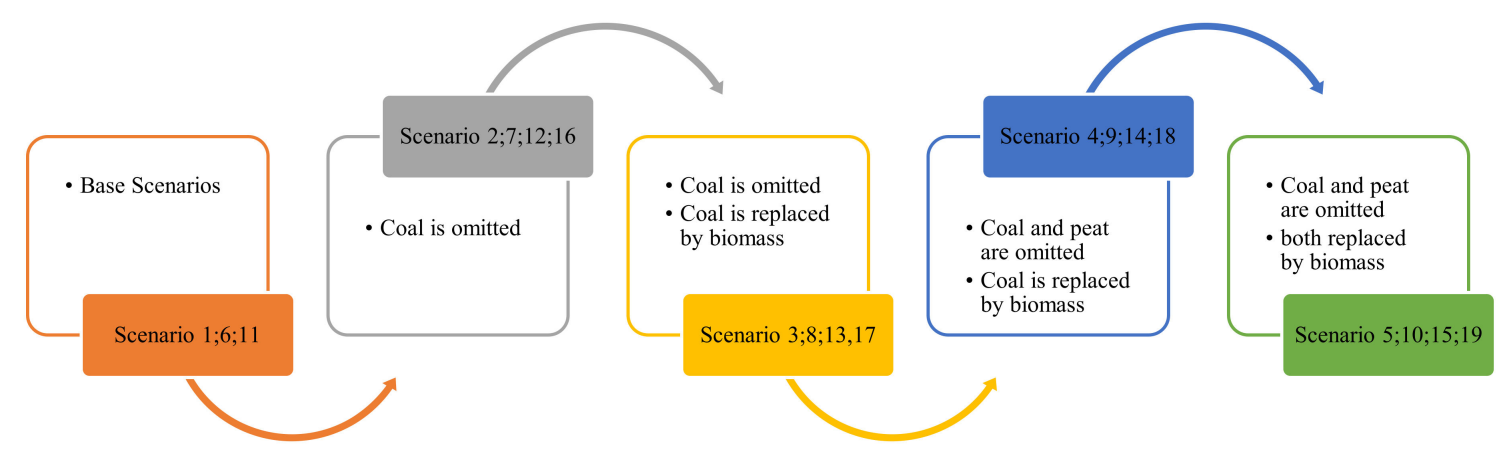

Figure 4. Different scenarios.

\subsection{Data}

Data were gathered from multiple sources at various time points during the study. Load and generation profiles were taken from the ENTSO-E Transparency Platform. The increase for 2030 was based on national forecasts [42]. Capacities, fuel prices (see Table A2), and efficiencies come from national statistics for the Nordic and Baltic countries and the Danish Energy Agency. Variable operation and maintenance costs have been estimated through companies' available information from public sources. Electricity demand and capacity mix for selected countries are set out in Table 7.

Table 7. Electricity demand and capacities in Finland and target countries.

\begin{tabular}{|c|c|c|c|c|c|c|c|c|c|c|}
\hline \multirow{2}{*}{ Year } & \multirow{2}{*}{ Country } & \multicolumn{4}{|c|}{ Electricity Demand } & \multicolumn{3}{|c|}{ Capacity (MW) } & \multirow[b]{2}{*}{ Other Thermal } & \multirow[b]{2}{*}{ Reserve } \\
\hline & & (TWh) & Wind & PV & Hydro & Nuclear & IndustrialCHP & CHP & & \\
\hline \multirow{9}{*}{2016} & FI & 84 & 1753 & - & 3112 & 2788 & 1972 & 3471 & 655 & 1575 \\
\hline & SE & 138 & 6417 & 103 & 16909 & 9139 & - & 3735 & 1878 & 705 \\
\hline & EE & 8 & 331 & - & 8 & - & - & - & 1633 & 250 \\
\hline & LV & 7 & 70 & - & 1565 & - & - & 1096 & 400 & - \\
\hline & LT & 11 & 509 & 70 & 127 & - & - & 1098 & 755 & 900 \\
\hline & FI_S2 & 84 & 1753 & - & 3112 & 2788 & 1783 & 2534 & 90 & 1337 \\
\hline & FI_S3 & 84 & 1753 & - & 3112 & 2788 & 1972 & 4036 & 90 & 1575 \\
\hline & FI_S4 & 84 & 1753 & - & 3112 & 2788 & 1897 & 3161 & 90 & 1575 \\
\hline & FI_S5 & 84 & 1753 & - & 3112 & 2788 & 1972 & 4036 & 90 & 1575 \\
\hline \multirow{9}{*}{2030} & FI & 92 & 3252 & - & 3112 & 4388 & 1972 & 5106 & 397 & 1532 \\
\hline & SE & 141 & 9013 & 103 & 16742 & $6949^{1}$ & 1982 & 3097 & 771 & 705 \\
\hline & $\mathrm{EE}$ & 10 & 445 & - & 8 & - & - & - & 1182 & 250 \\
\hline & LV & 9.5 & 310 & - & 1589 & - & - & 584 & 19 & - \\
\hline & LT & 14 & 800 & 80 & 141 & - & - & 498 & 343 & 900 \\
\hline & FI_S7 & 92 & 3252 & - & 3112 & 4388 & 1972 & 4124 & 397 & 1421 \\
\hline & FI_S8 & 92 & 3252 & - & 3112 & 4388 & 1972 & 5106 & 397 & 1532 \\
\hline & FI_S9 & 92 & 3252 & - & 3112 & 4388 & 1972 & 4084 & 397 & 1532 \\
\hline & FI_10 & 92 & 3252 & - & 3112 & 4388 & 1972 & 5106 & 397 & 1532 \\
\hline
\end{tabular}

${ }^{1}$ For Scenario 6-10 this value is obtained from 2016.

\section{Results}

In this section, different sets of figures and tables are used to clarify the impacts of removing hard coal in Finland.

\subsection{Changes in Electricity Supply and Prices}

Figure 5 presents an overview of yearly average electricity prices in Finland, Sweden, and the Baltic countries, studied in this paper in different scenarios. When removing coal-fired and peat-fired generation in Finland, we allowed replacement of a similar capacity based on biomass fuels. Thus, the total electricity and CHP capacity would remain the same in Finland, only being replaced by more expensive carbon-neutral fuel. 


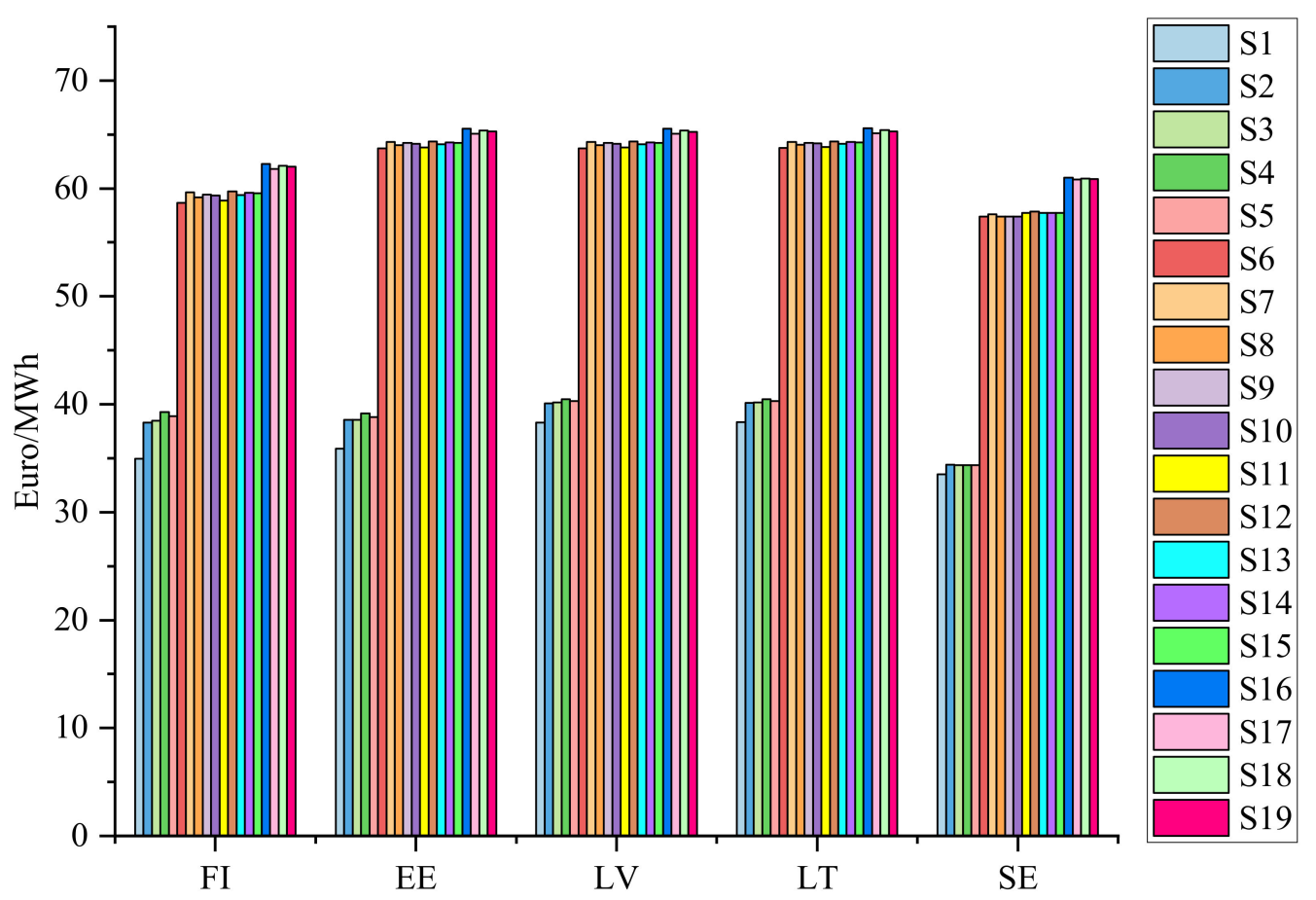

Figure 5. Annual average electricity prices in different scenarios for the target regions.

As can be seen, there is a clear trend of increases in prices of all countries by moving from 2016 to 2030. Estonia experiences the biggest increase. This dramatic change is due to the $\mathrm{CO}_{2}$ emission cost for 2030, which can make this country dependent on imports from Finland. Then Sweden is the second country with the most variation in prices from 2016 to 2030. In fact, more expensive technologies have been used to meet the electricity demand and make the prices higher. What stands out in the figure is the maximum price in all scenarios which could be found in the last four scenarios where the import from Norway is not allowed to increase. Then the most expensive units would be applied to generate electricity.

Figure 6 presents electricity production in the scenarios studied. For Finland, in all 2030 scenarios, the assumed amount of nuclear power is significantly larger than in 2016 due to the entry of the Olkiluoto $31600 \mathrm{MW}$ reactor. It can be seen that the amount of electricity generation with fossil fuels in 2030 decreases dramatically compared to 2016. When coal is omitted, the lack of supply is provided by natural gas and imports. In 2016, the import is mostly covering the lack of coal as it would be cheaper than generating with biomass. However, in 2030, the role of import is less vital, as in 2030, removing coal affects the net import of around $11 \%$ from the base scenarios, while this effect is around $42 \%$ in 2016. Removing peat affects net import, natural gas, and biomass production. Thus, natural gas would remain a significant fuel and forest-based biomass fuels would increase significantly. The assumed constant import from Norway would grow the electricity generation from combustible fuels in all countries. The assumed 2000 MW reduction in nuclear generation in Sweden would increase the electricity generation from combustible fuels only slightly if increased import from Norway is allowed. In that case, there would be a significant increase in Swedish electricity generation from natural gas. Finland's net import decreases significantly from 2016 to 2030 due to the newly installed capacities of nuclear power. (For electricity production in Finland see Table A1).

In Estonia, the assumed high price of $\mathrm{CO}_{2}$ emissions in 2030 is making the use of oil shale in electricity generation less competitive, and its use would decrease to almost one-third by 2030 in practically all scenarios. The reduced amount of generation is replaced by biomass as well as wind and import from Finland and Latvia.

The significantly increased use of gas-fired generation both in Latvia and in Lithuania by 2030 is due to the increase in demand and installed capacity. Demand increases to $32 \%$ and $24 \%$ in Latvia and 
Lithuania, respectively. The total amount of electricity generation in the base scenarios $(\mathrm{S} 6, \mathrm{~S} 11)$ would increase to $70 \%$ in Latvia and $62 \%$ in Lithuania from 2016 to 2030, respectively.

Finland

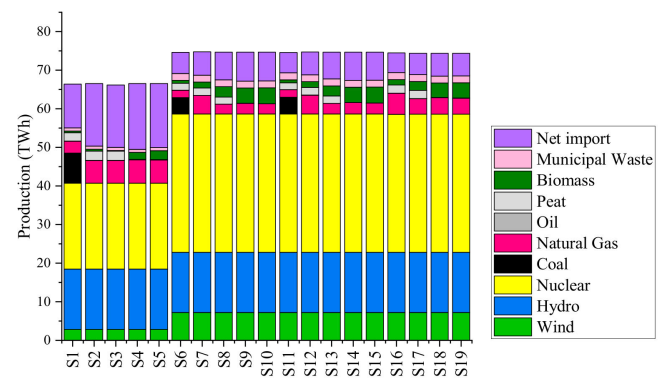

Sweden

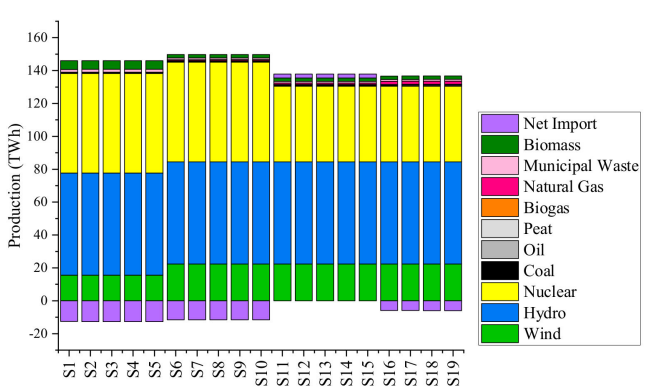

Estonia

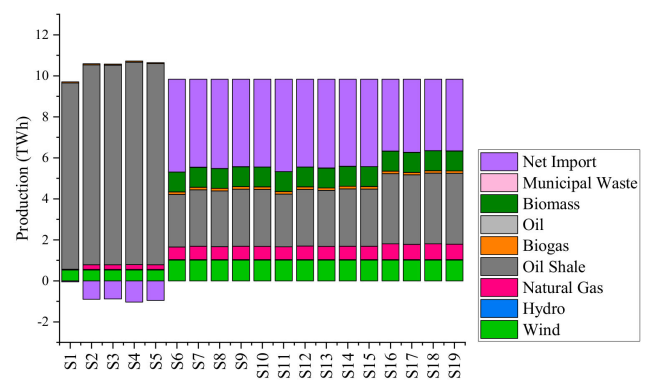

Latvia-Lithuania

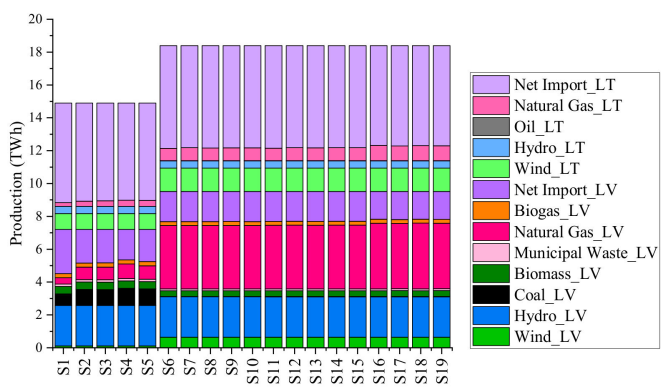

Figure 6. Target countries' electricity production in different scenarios in 2016 and 2030.

\subsection{Impacts on $\mathrm{CO}_{2}$ Emissions}

The Finnish regulation regarding removing hard coal is aimed to decrease $\mathrm{CO}_{2}$ emissions. As hard coal and peat are the two most $\mathrm{CO}_{2}$ emission-intensive fuels in Finland, it is interesting to compare the results after removing these fuels. Figure 7 provides the results obtained from the analysis. It is apparent from the figure that removing these fuels in Finland results in a large fall in $\mathrm{CO}_{2}$ emissions. However, although the whole region's $\mathrm{CO}_{2}$ emission decreases (FI, SE, EE, LV, LT), other countries rather than Finland, face a slight increase in their emissions due to the removed or more expensive production capacity in Finland. Estonia's main fuel for electricity production is oil shale. Owing to the expensive $\mathrm{CO}_{2}$ emission cost in 2030, Estonia would produce less and become a net importer (Figure A1). Thus, its emission will dramatically fall. No significant difference in the amount of emissions is detected in Latvia and Sweden, while Lithuania's emissions increase due to the growing use of natural gas and its import from Belarus is considered constant as in 2016. Closer inspection of the figure shows that all countries in 2030 emit more when further import from Norway is not allowed. 


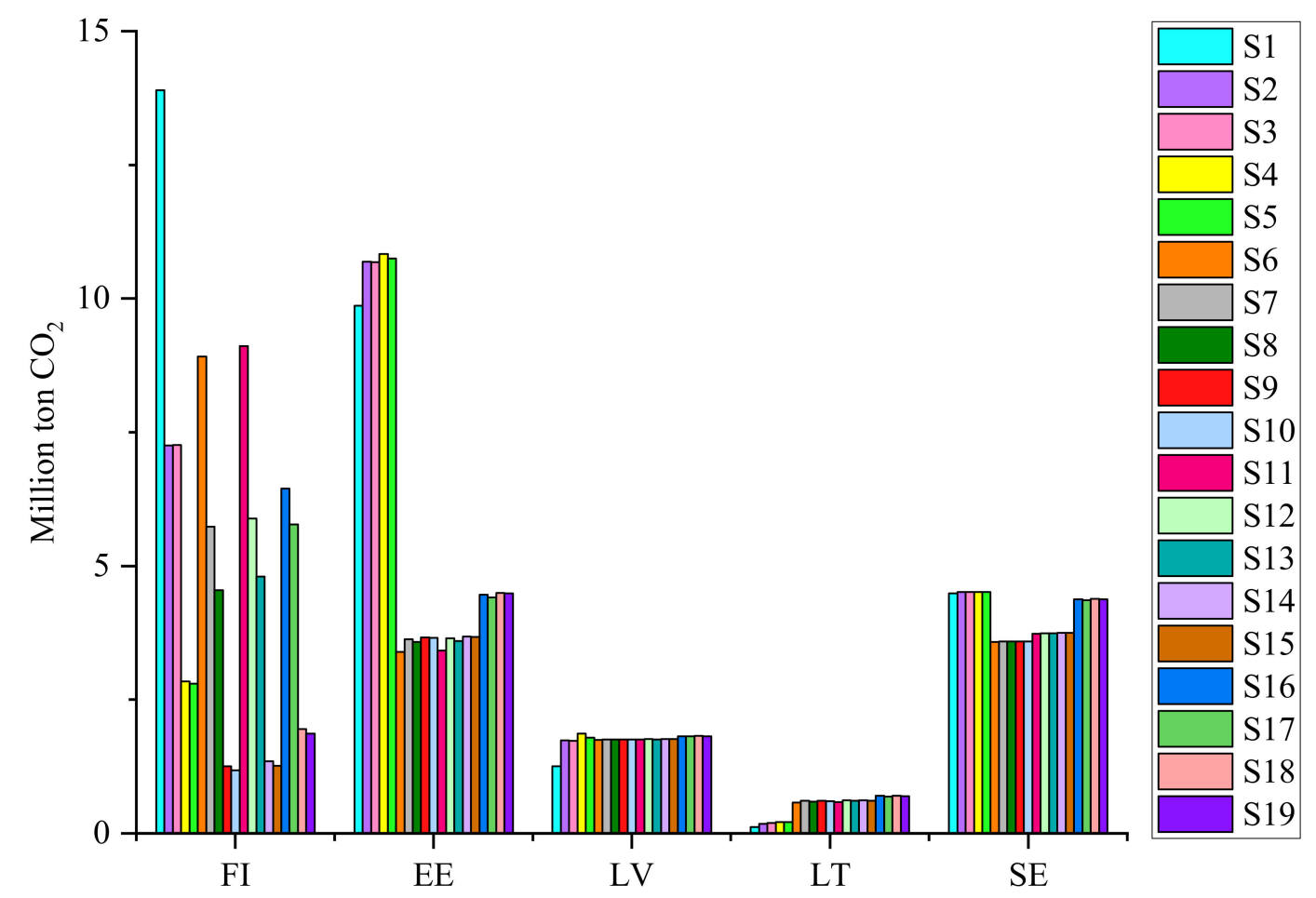

Figure 7. $\mathrm{CO}_{2}$ emissions from electricity and combined heat and power (CHP) production in different scenarios in 2016 and 2030.

Table 8 presents $\mathrm{CO}_{2}$ emissions, the net import of Sweden from Denmark, Norway, Germany, Poland, and the net import of the region. The region consists of Finland, Sweden, and the Baltic countries which have been studied in this paper. To get a better insight into Poland's effect on the results, the study is also done using the 2016 electricity prices of Poland. By omitting coal and peat-fired generations, the whole region would be more dependent on imports. What is interesting about the data in the table is that Sweden would face a significant rise in import from Norway and Denmark by phasing out nuclear power plants (Scenarios 11-15). When increased import from Norway is not allowed, Denmark will play a vital role in providing electricity for Sweden. From scenario 15 to 16, the region's net import significantly drops. Then, countries will need generation by more expensive domestic technologies. This leads to an increase in electricity prices along with a decrease in net imports.

Comparing the two results, it can be seen that the fall in Poland's electricity prices would decrease the $\mathrm{CO}_{2}$ emission and increase the net import of the region. But it is important to remember that low- $\mathrm{CO}_{2}$ electricity export from Sweden to Poland would reduce efficiently the $\mathrm{CO}_{2}$ emissions in Poland.

Figure 8 shows the primary energy use of biomass in different scenarios. It is apparent from the figure that removing coal and peat could dramatically increase biomass consumption. These results are not encouraging, as using an enormous amount of wood biomass would lead to decreasing carbon sinks and thus jeopardizing Finland's carbon neutrality target. 
Table 8. $\mathrm{CO}_{2}$ emissions from electricity and CHP production (including all CHP operations) in the modeled regions. Additionally, electricity imported from selected countries to Sweden is shown.

\begin{tabular}{|c|c|c|c|c|c|c|c|c|c|c|c|c|c|c|c|c|c|c|c|c|c|c|}
\hline \multirow[b]{2}{*}{ Scenarios } & \multicolumn{6}{|c|}{$\begin{array}{l}\mathrm{CO}_{2} \text { Emission } \\
\left.(\mathrm{Mt} \mathrm{CO})_{2}\right)\end{array}$} & \multicolumn{4}{|c|}{$\begin{array}{l}\text { Sweden Net Import from } \\
\text { Selected Countries (TWh) }\end{array}$} & \multicolumn{3}{|l|}{ Net Import } & \multicolumn{4}{|c|}{$\begin{array}{l}\mathrm{CO}_{2} \text { Emission } \\
\left(\mathrm{Mt} \mathrm{CO}_{2}\right) \\
\text { PL Prices 2016 }\end{array}$} & \multicolumn{4}{|c|}{$\begin{array}{l}\text { Sweden Net Import from } \\
\text { Selected Countries (TWh) }\end{array}$} & \multirow{2}{*}{$\begin{array}{c}\text { Net Import } \\
\text { Region (TWh) }\end{array}$} \\
\hline & FI & EE & LV & LT & $\mathrm{SE}$ & Total & DK & NO & $\mathrm{DE}$ & PL & Region (TWh) & FI & EE & LV & LT & SE & Total & DK & NO & $\mathrm{DE}$ & PL & \\
\hline $\mathrm{S} 1$ & 13.90 & 9.87 & 1.26 & 0.12 & 4.49 & 29.63 & 2.40 & 9.02 & -0.69 & -3.21 & 7.49 & & & & & & & & & & & \\
\hline S2 & 7.26 & 10.69 & 1.74 & 0.18 & 4.52 & 24.38 & 3.72 & 10.46 & -0.46 & -3.09 & 10.67 & & & & & & & & & & & \\
\hline S3 & 7.26 & 10.68 & 1.73 & 0.20 & 4.51 & 24.39 & 3.70 & 10.41 & -0.46 & -3.10 & 10.60 & & & & & & & & & & & \\
\hline S4 & 2.84 & 10.84 & 1.87 & 0.22 & 4.52 & 20.28 & 3.88 & 10.68 & -0.43 & -3.09 & 11.11 & & & & & & & & & & & \\
\hline S5 & 2.80 & 10.75 & 1.79 & 0.21 & 4.51 & 20.07 & 3.81 & 10.53 & -0.45 & -3.10 & 10.86 & & & & & & & & & & & \\
\hline S6 & 8.92 & 3.40 & 1.75 & 0.58 & 3.58 & 18.23 & 5.12 & 11.28 & -4.57 & -5.09 & 6.49 & 8.84 & 3.05 & 1.70 & 0.52 & 3.55 & 17.65 & 3.78 & 10.28 & -4.63 & -3.01 & 6.77 \\
\hline S7 & 5.74 & 3.63 & 1.75 & 0.61 & 3.59 & 15.32 & 5.23 & 11.45 & -4.56 & -5.09 & 6.80 & 5.70 & 3.29 & 1.70 & 0.54 & 3.55 & 14.79 & 3.89 & 10.42 & -4.62 & -3.00 & 7.06 \\
\hline S8 & 4.55 & 3.58 & 1.75 & 0.60 & 3.59 & 14.07 & 5.75 & 12.09 & -4.56 & -5.08 & 7.98 & 4.50 & 3.23 & 1.70 & 0.53 & 3.55 & 13.51 & 4.41 & 11.09 & -4.62 & -2.98 & 8.28 \\
\hline S9 & 1.25 & 3.67 & 1.76 & 0.61 & 3.59 & 10.87 & 5.79 & 12.26 & -4.55 & -5.08 & 8.22 & 1.21 & 3.32 & 1.70 & 0.54 & 3.55 & 10.33 & 4.46 & 11.23 & -4.61 & -2.97 & 8.51 \\
\hline S10 & 1.18 & 3.65 & 1.75 & 0.60 & 3.59 & 10.78 & 5.82 & 12.20 & -4.56 & -5.08 & 8.17 & 1.14 & 3.30 & 1.70 & 0.54 & 3.55 & 10.23 & 4.48 & 11.19 & -4.62 & -2.97 & 8.47 \\
\hline S11 & 9.11 & 3.42 & 1.76 & 0.59 & 3.73 & 18.60 & 11.18 & 18.30 & -4.20 & -4.85 & 20.28 & 9.01 & 3.06 & 1.70 & 0.52 & 3.65 & 17.95 & 9.70 & 17.28 & -4.37 & -2.33 & 20.75 \\
\hline $\mathrm{S} 12$ & 5.89 & 3.65 & 1.76 & 0.62 & 3.74 & 15.66 & 11.23 & 18.52 & -4.20 & -4.83 & 20.60 & 5.84 & 3.28 & 1.71 & 0.55 & 3.66 & 15.04 & 9.78 & 17.51 & -4.37 & -2.31 & 24.84 \\
\hline $\mathrm{S} 13$ & 4.80 & 3.60 & 1.76 & 0.61 & 3.74 & 14.51 & 11.67 & 19.11 & -4.16 & -4.83 & 21.66 & 4.74 & 3.53 & 1.75 & 0.60 & 3.67 & 14.30 & 10.98 & 17.94 & -2.15 & -4.96 & 21.65 \\
\hline S14 & 1.35 & 3.68 & 1.76 & 0.62 & 3.75 & 11.16 & 11.68 & 19.28 & -4.14 & -4.81 & 21.90 & 1.27 & 3.32 & 1.71 & 0.55 & 3.66 & 10.50 & 10.24 & 18.28 & -4.34 & -2.21 & 22.45 \\
\hline S15 & 1.27 & 3.67 & 1.76 & 0.61 & 3.75 & 11.06 & 11.74 & 19.20 & -4.15 & -4.82 & 21.86 & 1.19 & 3.30 & 1.71 & 0.54 & 3.66 & 10.40 & 10.30 & 18.20 & -4.34 & -2.23 & 22.42 \\
\hline S16 & 6.45 & 4.46 & 1.82 & 0.71 & 4.38 & 17.82 & 15.14 & & -1.49 & -2.50 & 10.46 & 6.34 & 3.97 & 1.77 & 0.65 & 4.17 & 16.91 & 13.94 & & -2.55 & 0.18 & 11.40 \\
\hline S17 & 5.78 & 4.41 & 1.81 & 0.69 & 4.36 & 17.05 & 15.70 & & -1.46 & -2.54 & 11.00 & 5.58 & 3.88 & 1.76 & 0.63 & 4.16 & 16.00 & 14.52 & & -2.51 & 0.30 & 12.15 \\
\hline S18 & 1.95 & 4.49 & 1.82 & 0.70 & 4.39 & 13.36 & 15.68 & & -1.40 & -2.44 & 11.16 & 1.78 & 4.00 & 1.78 & 0.64 & 4.18 & 12.38 & 14.50 & & -2.45 & 0.34 & 12.24 \\
\hline S19 & 1.87 & 4.49 & 1.82 & 0.69 & 4.38 & 13.24 & 15.80 & & -1.43 & -2.49 & 11.20 & 1.69 & 3.96 & 1.77 & 0.63 & 4.17 & 12.22 & 14.64 & & -2.47 & 0.33 & 12.33 \\
\hline
\end{tabular}




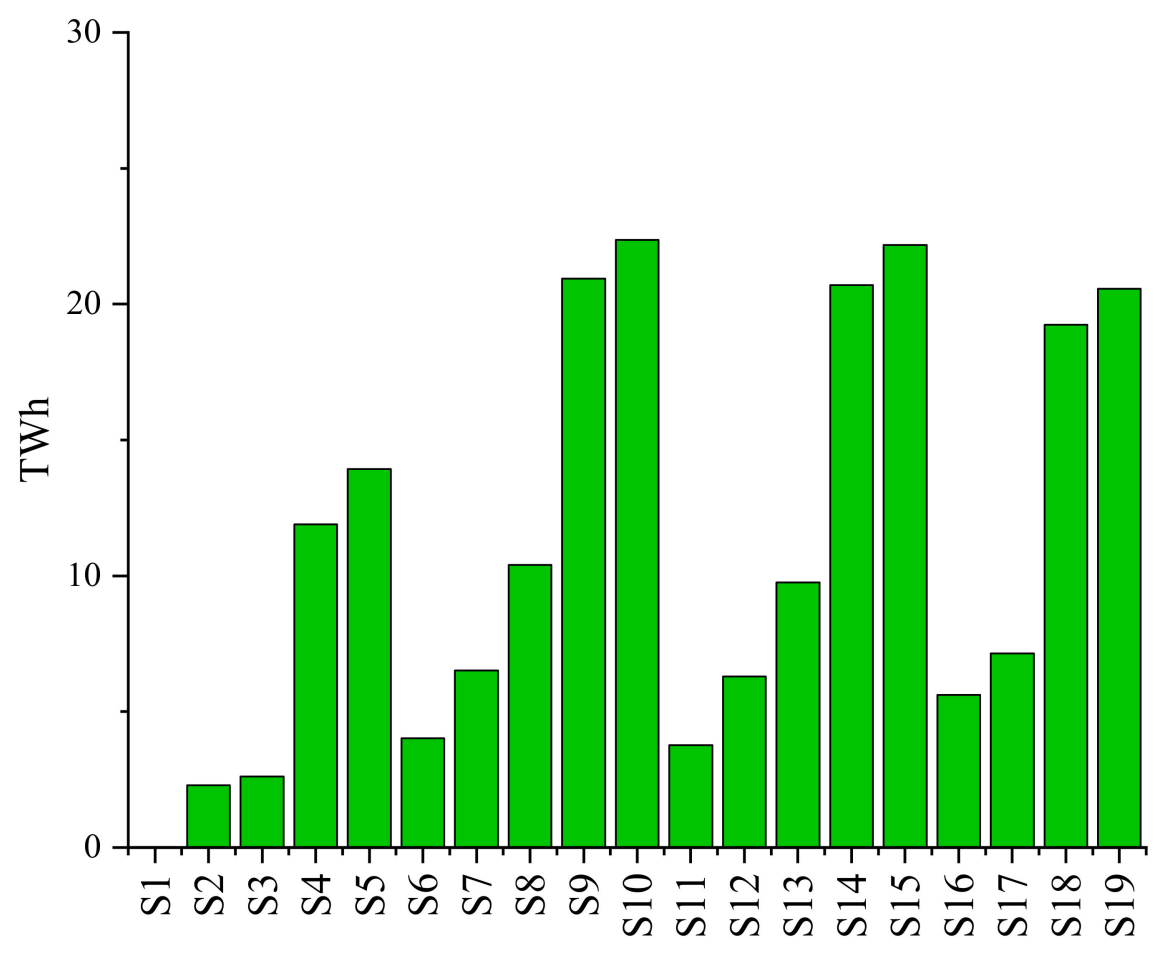

Figure 8. Biomass primary energy use in Finland in different scenarios.

\section{Discussion and Conclusions}

This study set out to analyze the impacts of removing hard coal and peat and replacing them by similar biomass CHP generation in the electricity and district heating sector in Finland. The aim was to investigate the plausible impacts on Nordic and Baltic countries through the strongly interconnected international electricity market. Different scenarios were surveyed, including the planned nuclear restrictions for Sweden by 2030. In 2030 scenarios, export from Norway to Sweden is used extensively to cover up the deficit from Swedish nuclear closure and closure of Finnish coal and peat-fired generation. This is not realistic, as extensive connections exist and are being enforced between Norway and the UK and Central European markets. Thus, our last four scenarios modeled the cases without the possibility to increase imports from Norway.

The results show that national-level energy policies have significant impacts on wider regions, especially when the policies target power plants operating on strongly connected international markets. Policies that fail to take these impacts into account may lead to unwanted adverse effects. In this case, the ambitious legislation abandoning coal use in Finland may well lead to increased electricity import from a wider market area (Finland, Sweden, Estonia, Latvia, and Lithuania) and outside it, mostly from regions with carbon-intensive generation. The increased imports are also not desirable from the point of energy security and electricity system reliability, especially during winter time demand peaks [43].

In this study, it was assumed that coal and peat fired power plants would be replaced by similar plants using biomass fuels. This increases the total biomass needs by a considerable amount. If coal and peat are replaced by biomass fuels, the additional need for biomass fuel would be even more than 20 TWh. The use of natural gas would also increase in Finland.

The results show that especially in the Baltic countries, electricity prices would increase considerably from 2016 to 2030, mainly due to the assumed higher EU ETS $\mathrm{CO}_{2}$ allowance prices, cutting the Estonian oil shale-based electricity generation from 9TWh in 2016 to 2.5 TWh in 2030 (Scenario 6). These countries have a much lower GPD per capita than, for example, the Nordic countries. Thus, there is a significant risk of increasing energy poverty among the population in the near future. This calls for transmission investments and ensuring the adequate cost-efficient supply of both electricity and heat in the region. 
Omitting coal and peat leads to a fall in domestic $\mathrm{CO}_{2}$ emissions, while net import to the region from more coal-intensive countries increases. The second major finding is that only Finland in the region will face a decrease in $\mathrm{CO}_{2}$ emissions and other countries experience a slight increase. The increase in net imports is mainly due to the import of Sweden from Denmark and Norway. In scenarios where increased import from Norway is not possible, Denmark plays a critical role in providing electricity for the region. Moreover, more expensive domestic generation is used which leads to a rise in $\mathrm{CO}_{2}$ emissions. For instance, Lithuania would use more natural gas CHP for electricity and heat generation.

This study provides a deeper insight into the effects of Finland's legislation on banning the use of coal. Since the study was limited to Finland, Sweden, and the Baltic countries, the forthcoming UK transmission lines with Norway were not considered by 2030. Thus, the import from Norway was affected by this assumption. However, we try to detract this issue by defining the last four scenarios where no more import from Norway is allowed. Further work needs to be done to explore the effect of UK transmission lines with Norway. Moreover, modeling work will have to be conducted in order to determine the whole Nordic electricity market and focus on determining different $\mathrm{CO}_{2}$ prices. In Sweden, Denmark, and Norway, bidding zones can be studied in detail to make better policies. Electricity demand is one of the essential parameters that affect results. Electric cars and micro-generation are examples that could change the estimate for the electricity demand profile. For the 2030 horizon, an uncertainty interval could be assumed for electricity demand in Finland and analyze the impacts of national policies in the presence of demand uncertainty.

Author Contributions: A.F. collected the required data and performed the modeling work. S.S. supervised the modeling and writing processes. V.O. collected the required data, supported model development and result validation and participated in the Modeling section. A.F., V.O. and S.S. wrote the manuscript. A.K. supported developing scenarios. All authors contributed significantly to the design of the scenarios and the presented analyses, and to reviewing the manuscript. All authors have read and agreed to the published version of the manuscript.

Acknowledgments: We acknowledge the funding from the Aalto University, Science Institute and the School of Engineering. We thank Lina Reichenberg from Aalto University and the Chalmers University of Technology for comments.

Conflicts of Interest: The authors declare no conflict of interest.

\section{Appendix A}

Table A1. Electricity production in Finland (TWh).

\begin{tabular}{lccccccccc}
\hline FI & Wind & Hydro & Nuclear & Coal & Natural Gas & Oil & Peat & Biomass & Municipal Waste \\
\hline S1 & 2.86 & 15.61 & 22.26 & 7.77 & 3.10 & 0.01 & 2.18 & 0.45 & 0.80 \\
S2 & 2.86 & 15.61 & 22.26 & 0.00 & 5.83 & 0.05 & 2.42 & 0.49 & 0.80 \\
S3 & 2.86 & 15.61 & 22.26 & 0.00 & 5.84 & 0.05 & 2.43 & 0.15 & 0.80 \\
S4 & 2.86 & 15.61 & 22.26 & 0.00 & 6.07 & 0.08 & 0.00 & 1.81 & 0.80 \\
S5 & 2.86 & 15.61 & 22.26 & 0.00 & 6.01 & 0.07 & 0.00 & 2.33 & 0.80 \\
S6 & 7.19 & 15.61 & 35.86 & 4.23 & 1.91 & 0.01 & 1.77 & 0.80 & 1.78 \\
S7 & 7.19 & 15.61 & 35.86 & 0.00 & 4.78 & 0.03 & 1.93 & 1.51 & 1.78 \\
S8 & 7.19 & 15.61 & 35.86 & 0.00 & 2.52 & 0.01 & 1.85 & 2.68 & 1.78 \\
S9 & 7.19 & 15.61 & 35.86 & 0.00 & 2.74 & 0.02 & 0.00 & 3.94 & 1.78 \\
S10 & 7.19 & 15.61 & 35.86 & 0.00 & 2.61 & 0.02 & 0.00 & 4.14 & 1.78 \\
S11 & 7.19 & 15.61 & 35.87 & 4.30 & 1.96 & 0.01 & 1.81 & 0.76 & 1.79 \\
S12 & 7.19 & 15.61 & 35.87 & 0.00 & 4.85 & 0.03 & 1.99 & 1.49 & 1.79 \\
S13 & 7.19 & 15.61 & 35.87 & 0.00 & 2.71 & 0.02 & 1.93 & 2.60 & 1.79 \\
S14 & 7.19 & 15.61 & 35.87 & 0.00 & 2.94 & 0.03 & 0.00 & 3.92 & 1.79 \\
S15 & 7.19 & 15.61 & 35.87 & 0.00 & 2.81 & 0.02 & 0.00 & 4.12 & 1.79 \\
S16 & 7.19 & 15.61 & 35.77 & 0.00 & 5.41 & 0.05 & 2.13 & 1.41 & 1.79 \\
S17 & 7.19 & 15.61 & 35.79 & 0.00 & 4.04 & 0.02 & 2.12 & 2.28 & 1.79 \\
S18 & 7.19 & 15.61 & 35.79 & 0.00 & 4.28 & 0.04 & 0.00 & 3.74 & 1.79 \\
S19 & 7.19 & 15.61 & 35.79 & 0.00 & 4.16 & 0.02 & 0.00 & 3.92 & 1.79 \\
\hline
\end{tabular}




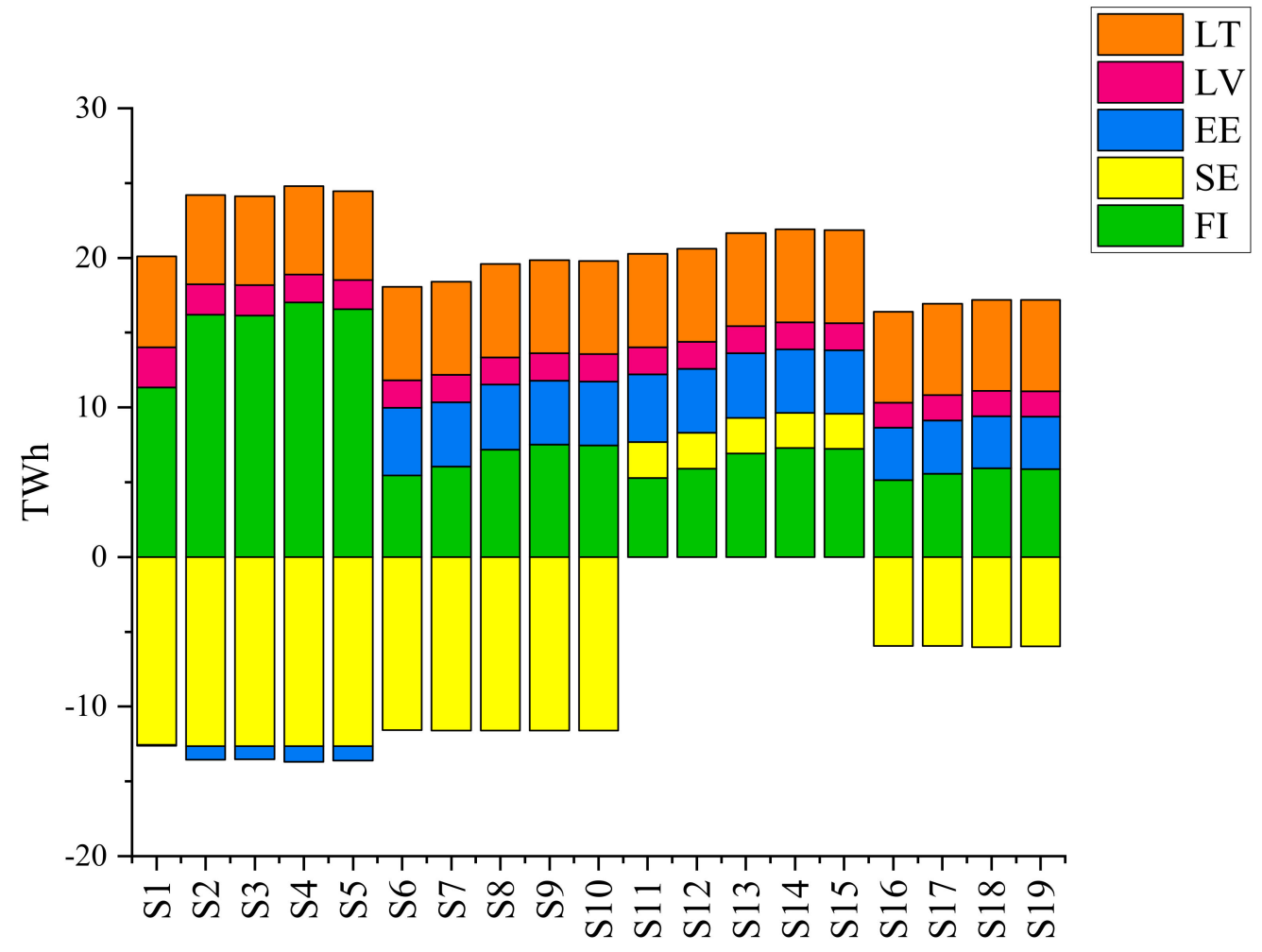

Figure A1. Selected countries' net import.

Table A2. Fuel prices for selected countries (Euro/MWh).

\begin{tabular}{ccccccccccc}
\hline Fuel & \multicolumn{9}{c}{$\mathbf{2 0 1 6}$} & \multicolumn{7}{c}{$\mathbf{2 0 3 0}$} \\
\cline { 2 - 11 } & FI & EE & LV & LT & SE & FI & EE & LV & LT & SE \\
\hline Biogas & 19 & 1 & 16 & - & 10 & 19 & 1 & 16 & - & 10 \\
Waste Liquors & 1 & - & - & - & 3 & 1 & - & - & - & 3 \\
Blastfurnace Gas & - & - & 1 & - & - & - & - & 1 & - & - \\
Forest Fuel wood & 21 & 12 & 7 & 1 & - & 25 & 12 & 7 & 1 & - \\
Fuel Oil & 34 & 41 & 41 & 41 & 34 & 42 & 42 & 42 & 42 & 42 \\
Hard Coal & 8 & 7 & 9 & - & 11 & 8 & 8 & 8 & - & 8 \\
Heavy Fuel Oil & 22 & 30 & 29 & 40 & 38 & 42 & 42 & 42 & 42 & 42 \\
Hydrogen & 1 & - & - & - & - & 1 & - & - & - & - \\
IndustryWood Residue & 21 & - & 3 & - & - & 25 & - & 3 & - & - \\
Kerosene & - & - & - & - & 26 & - & - & - & - & 26 \\
Landfill Gas & - & 1 & - & - & 10 & - & 1 & - & - & 10 \\
Light Fuel Oil & 34 & 41 & - & - & 34 & 42 & 42 & - & - & 42 \\
Milled Peat & 13 & 1 & - & - & 26 & 13 & 1 & - & - & 26 \\
Municipal Waste & 1 & 35 & 1 & - & 1 & 0 & 35 & 1 & - & -5 \\
Natural Gas & 21 & 28 & 26 & 30 & 35 & 24 & 24 & 24 & 24 & 24 \\
Oil Shale & - & 5 & - & - & - & - & 8 & - & - & - \\
Reaction Heat Of Industry & - & - & - & 1 & 1 & - & - & - & 1 & 1 \\
Refinery Gas & - & - & - & - & 7 & - & - & - & - & 7 \\
Sod Peat & 17 & - & - & - & 16 & 17 & - & - & - & 16 \\
Straw & - & 8 & 8 & - & - & - & 22 & 22 & - & - \\
Uranium Oxide & 2 & 1 & - & - & 2 & 2 & 1 & - & - & 2 \\
Wood Chips & - & - & 3 & - & 8 & - & - & 26 & - & 26 \\
Wood Pellet & 44 & - & 24 & - & 28 & 32 & - & 32 & - & 32 \\
Solid Fuel & - & - & - & 8 & - & - & - & - & 8 & - \\
\hline
\end{tabular}

${ }^{1}$ Latvia imposed subsidy on natural gas in CHP production. 


\section{References}

1. UNFCCC. The Paris Agreement; UNFCCC: New York, NY, USA. Available online: https://unfccc.int/processand-meetings/the-paris-agreement/the-paris-agreement (accessed on 13 March 2020).

2. Amanatidis, G. European policies on climate and energy towards 2020, 2030 and 2050. 2019. Available online: www.europarl.europa.eu/supporting-analyses (accessed on 25 November 2019).

3. IEA. Nordic Energy Technology Perspectives 2016: Cities, Flexibility and Pathways to Carbon-Neutrality; IEA: Paris, France, 2016.

4. FINLEX FINLEX ®—Säädökset alkuperäisinä: Laki hiilen energiakäytön kieltämisestä 416/2019. Available online: https://www.finlex.fi/fi/laki/alkup/2019/20190416 (accessed on 14 January 2020).

5. HELEN. Company Vuosaari Power Plants; HELEN: Helsinki, Finland. Available online: https://www.helen.fi/ en/company/energy/energy-production/power-plants/vuosaari-power-plants (accessed on 14 January 2020).

6. Fortum. All Inkoo coal-fired power plant boiler buildings have been demolished and $92 \%$ of the materials have been recycled; Fortum: Espoo, Finland. Available online: https:/www.fortum.com/media/2019/12/all-inkoo-coal-firedpower-plant-boiler-buildings-have-been-demolished-and-92-materials-have-been-recycled (accessed on 14 January 2020).

7. Fortum. Fortum's Meri-Pori Power Plant Selected for Peak-Load Reserve Capacity System for the Period 1 July 2020-30 June 2022; Fortum: Espoo, Finland; Available online: https://www.fortum.com/media/2019/12/fortums-meripori-power-plant-selected-peak-load-reserve-capacity-system-period-1-july-2020-30-june-2022 (accessed on 11 February 2020).

8. Energia Energiateollisuus. Available online: https://energia.fi/ (accessed on 14 January 2020).

9. Moro, A.; Lonza, L. Electricity carbon intensity in European Member States: Impacts on GHG emissions of electric vehicles. Transp. Res. Part. Transp. Environ. 2018, 64, 5-14. [CrossRef] [PubMed]

10. Purvins, A.; Fulli, G.; Covrig, C.-F.; Chaouachi, A.; Bompard, E.F.; Carpaneto, E.; Huang, T.; Pi, R.J.; Mutule, A.; Oleinikova, I.; et al. The Baltic Power System between East and West. Interconnections. First Results from a Security Analysis and Insights for Future Work; European Union Joint Research Centre: Brussels, Belgium, 2016; p. 52.

11. Zakeri, B.; Virasjoki, V.; Syri, S.; Connolly, D.; Mathiesen, B.V.; Welsch, M. Impact of Germany's energy transition on the Nordic power market - A market-based multi-region energy system model. Energy 2016, 115, 1640-1662. [CrossRef]

12. Zakeri, B.; Price, J.; Zeyringer, M.; Keppo, I.; Mathiesen, B.V.; Syri, S. The direct interconnection of the UK and Nordic power market - Impact on social welfare and renewable energy integration. Energy 2018, 162, 1193-1204. [CrossRef]

13. Newcomer, A.; Apt, J. Near-Term Implications of a Ban on New Coal-Fired Power Plants in the United States. Environ. Sci. Technol. 2009, 43, 3995-4001. [CrossRef] [PubMed]

14. Lund, H.; Mathiesen, B.V. Energy system analysis of 100\% renewable energy systems-The case ofDenmark in years 2030 and 2050. Energy 2009, 34, 524-531.

15. Venkatesh, A.; Jaramillo, P.; Griffin, W.M.; Matthews, H.S. Implications of Near-Term Coal Power Plant Retirement for $\mathrm{SO}_{2}$ and $\mathrm{NO}_{x}$ and Life Cycle GHG Emissions. Environ. Sci. Technol. 2012, 46, 9838-9845. [CrossRef] [PubMed]

16. Elliston, B.; MacGill, I.; Diesendorf, M. Comparing least cost scenarios for $100 \%$ renewable electricity with low emission fossil fuel scenarios in the Australian National Electricity Market. Renew. Energy 2014, 66, 196-204. [CrossRef]

17. Heinrichs, H.U.; Markewitz, P. Long-term impacts of a coal phase-out in Germany as part of a greenhouse gas mitigation strategy. Appl. Energy 2017, 192, 234-246. [CrossRef]

18. Pilpola, S.; Lund, P.D. Effect of major policy disruptions in energy system transition: Case Finland. Energy Policy 2018, 116, 323-336. [CrossRef]

19. Hong, S.; Qvist, S.; Brook, B.W. Economic and environmental costs of replacing nuclear fission with solar and wind energy in Sweden. Energy Policy 2018, 112, 56-66. [CrossRef]

20. Hansen, K.; Mathiesen, B.V.; Skov, I.R. Full energy system transition towards $100 \%$ renewable energy in Germany in 2050. Renew. Sustain. Energy Rev. 2019, 102, 1-13. [CrossRef]

21. NORDPOOL. Day-Ahead Overview. Available online: https://www.nordpoolgroup.com/maps/ (accessed on 1 April 2020). 
22. European Commission. Final Report of the Sector Inquiry on Capacity Mechanisms; European Commission: Brussels, Belgium, 2016.

23. World Energy Council (WEC). Energy Trilemma Index Tool. Available online: https://trilemma.worldenergy. org/ (accessed on 26 November 2019).

24. European Commission. 2020 Climate \& Energy Package. Available online: https://ec.europa.eu/clima/ policies/strategies/2020_en (accessed on 1 April 2020).

25. Dijkstra, L.; Athanasoglou, S. The Europe 2020 Index: The Progress of Europe Countries, Regions And Cities To The 2020 Targets; European Commission, Regional and Urban Policy: Brussels, Belgium, 2015.

26. European Commission. 2030 Climate \& Energy Framework. Available online: https://ec.europa.eu/clima/ policies/strategies/2030_en (accessed on 27 January 2020).

27. European Commission. EU Emissions Trading System (EU ETS). Available online: https://ec.europa.eu/ clima/policies/ets_en (accessed on 27 January 2020).

28. IEA. Data \& Statistics. Available online: https://www.iea.org/data-and-statistics (accessed on 27 January 2020).

29. OECD. Compare your Country-Climate Change Mitigation Policies. Available online: //www. compareyourcountry.org/climate-policies?lg=en (accessed on 10 February 2020).

30. Statistics Finland. Statistics Finland-Energy Supply and Consumption. Available online: https://www.stat. fi/til/ehk/2018/04/ehk_2018_04_2019-03-28_tie_001_en.html (accessed on 27 January 2020).

31. Ministry of Economic Affairs and Employment of Finland. Government Report on the National Energy and Climate Strategy for 2030; Ministry of Economic Affairs and Employment of Finland: Helsinki, Finland, 2017.

32. Statistics Finland. Electricity and heat production by production mode and fuel in 2016. Available online: https://www.stat.fi/til/salatuo/2016/salatuo_2016_2017-11-02_tau_001_en.html (accessed on 25 November 2019).

33. THE World Bank. Population-European Union Data. Available online: https://data.worldbank.org/indicator/ SP.POP.TOTL?locations=EU (accessed on 10 February 2020).

34. Eurostat GDP and main components. Available online: http://appsso.eurostat.ec.europa.eu/nui/ show.do?query=BOOKMARK_DS-406763_QID_1F4AE322_UID_-3F171EB0\&layout=TIME,C,X,0; GEO,L,Y,0;UNIT,L,Z,0;NA_ITEM,L,Z,1;INDICATORS,C,Z,2;\&zSelection=DS-406763UNIT,CP_MEUR; DS-406763INDICATORS,OBS_FLAG;DS-406763NA_ITEM,B1GQ;\&rankName1=TIME_1_0_0_0\& rankName2=UNIT_1_2_-1_2\&rankName3=GEO_1_2_0_1\&rankName4=INDICATORS_1_2_-1_2\& rankName5=NA-ITEM_1_2_-1_2\&sortC=ASC_-1_FIRST\&rStp=\&cStp=\&rDCh=\&cDCh=\&rDM=true\& $\mathrm{cDM}=$ true \&footnes $=$ false $\&$ empty $=$ false $\&$ wai $=$ false $\&$ time_mode $=$ NONE\&time_most_recent $=$ false \& lang=EN\&cfo= $\% 23 \% 23 \% 23 \% 2 \mathrm{C} \% 23 \% 23 \% 23 . \% 23 \% 23 \% 23$ (accessed on 10 February 2020).

35. Ministry of the Environment and Energy, Government Offices of Sweden. Sweden's Draft Integrated National Energy and Climate Plan; Ministry of the Environment and Energy, Government Offices of Sweden: Stockholm, Sweden, 2018.

36. Ministry of Economic Affairs and Communications of Republic of Estonia. National Development Plan. of the Energy Sector until 2030; Ministry of Economic Affairs and Communications of Republic of Estonia: Tallinn, Estonia, 2017; pp. 1-124.

37. European Commission. National Energy and Climate Plan of Latvia 2021-2030; European Commission: Brussels, Belgium, 2018.

38. Ministry of Energy, Ministry of Environment of the Republic of Lithuania. Integrated National Energy and Climate Plan of the Republic of Lithuania 2018; European Commission: Brussels, Belgium, 2018.

39. European Commission. Summary of the Commission assessment of the draft National Energy and Climate Plan 2021-2030; European Commission: Brussels, Belgium, 2018.

40. European Commission. Commission Recommendation on the draft integrated National Energy and Climate Plan of Estonia covering the period 2021-2030; European Commission: Brussels, Belgium, 2019.

41. Renã-Fãlt, B.M.; Jansson, R.; Nilsson, C. Effects of hydropower generation and opportunities for environmental flow management in Swedish riverine ecosystems: Hydropower and environmental flow management. Freshw. Biol. 2010, 55, 49-67. [CrossRef] 
42. Finnish Ministry of Economic Affairs and Employment. Taustaraportti Kansalliselle Energia-ja Ilmastostrategialle Vuoteen 2030 (Background Report for the National Energy and Climate Strategy Until Year 2030); Finnish Ministry of Economic Affairs and Employment: Helsinki, Finland, 2017.

43. Jääskeläinen, J.; Zakeri, B.; Syri, S. Adequacy of power capacity during winter peaks in Finland. In Proceedings of the 2017 14th International Conference on the European Energy Market (EEM), Dresden, Germany, 6-9 June 2017; pp. 1-6.

(C) 2020 by the authors. Licensee MDPI, Basel, Switzerland. This article is an open access article distributed under the terms and conditions of the Creative Commons Attribution (CC BY) license (http://creativecommons.org/licenses/by/4.0/). 